\title{
SYSTEM OF DIGITAL TRANSFORMATION INDICATORS IN TRANSPORT SECTOR
}

\author{
Doctor of Economics, PHD, Senior Researcher, Olena Nykyforuk, \\ PHD/Candidate of Economic Sciences, Researcher Olga Stasyuk, \\ Researcher Larysa Chmyrova, \\ Junior Research Natalia Fedyaj,
}

Ukraine, Kiev, Institute for Economics and Forecasting, National Academy of Sciences of Ukraine

DOI: https://doi.org/10.31435/rsglobal_ejits/31072019/6576

\section{ARTICLE INFO}

Received 23 May 2019

Accepted 20 July 2019

Published 31 July 2019

\section{KEYWORDS}

digital transformation, intelligent transport system, system of indicators for developments in the intelligent transport systems.

\begin{abstract}
The review of existing approaches to determining the systems that describe both the processes of economic sectors digitalisation and the ITS introduction in transport sector has underpinned the development and presentation of this approach to determining the digital transformation indicators in transport sector. Current stage of digital technology development is calling for defining and grouping the blocks, systems, subsystems filling them with appropriate indicators. The approach proposed defines the functional architecture of the digital transformations comprised of 3 blocks, 5 key systems of indicators and 18 subsystems representing both modern and envisaged transformation processes for digitalisation in transport with the view of ensuring their success in the future. This Article establishes and selects transport sector digital transformation indicators enabling the monitoring of transformation developments, holding assessments of digital transformations in progress that would constitute a basis for decision-making on ensuring the success for digital transformations in the transport industry.
\end{abstract}

Citation: Olena Nykyforuk, Olga Stasyuk, Larysa Chmyrova, Natalia Fedyaj. (2019) System of Digital Transformation Indicators in Transport Sector. European Journal of Intelligent Transportation Systems. 1(2). doi: 10.31435/rsglobal_ejits/31072019/6576.

Copyright: (C) 2019 Olena Nykyforuk, Olga Stasyuk, Larysa Chmyrova, Natalia Fedyaj. This is an open-access article distributed under the terms of the Creative Commons Attribution License (CC BY). The use, distribution or reproduction in other forums is permitted, provided the original author(s) or licensor are credited and that the original publication in this journal is cited, in accordance with accepted academic practice. No use, distribution or reproduction is permitted which does not comply with these terms.

Introduction. Over the past ten years, the digital technologies have changed more than over the past fifty years. This opens up new opportunities and poses challenges for a number of industries, transport included. This, in its turn, requires incorporating innovative solutions for digital transformations to be introduced into the transport sector operation and proceeding with the Intelligent Transport Systems, hereinafter the ITS, establishment and operation. Main issues of the transport sector at its current stage include as follows: enhancing traffic safety, fighting traffic congestion, delays due to mobility issues, road traffic capacity issues, environmental damages, deteriorated quality of life etc. All of that coupled with the growing impacts of logistics and multimodal carriage of passengers and freight require both innovative solutions in the management systems and developments in the technologies extending their application of digital solutions.

Digitalisation refers to the routine integrating digital technologies into the society's everyday life featuring the shift from analogue world to the digital communications and their multiple apps. The current stage holds the shifting from wide use and the Internet and Internet-technologies integration into operation processes and human life that would entail an era to be emerged, namely the Digital Society and Digital Economy Era employing digital infrastructure much further than as a supplementary contribution.

Findings of the study. For all the transport sector industries the digitalisation would entail, as appropriate, shifting towards the ITS deployment that would include the set of procedures, systems 
and applications enabling to enhance personal mobility, carriage of passengers and freight. The ITS's cover a wide range of wireless and wired communications based on electronic technologies. When integrated into the transport infrastructure and into the vehicles as such, these technologies enable to essentially unload, enhance safety and productivity of, the transport system in general.

Development and deployment of the ITS across the world is an efficient innovative business already now facilitating the solutions for a number of social and economic problems and the implementation of the counter-crisis measures. Moreover, the insight into transport system development documents suggests the ITS's have become compulsory in drafting strategic, political and program targeting documents of the developed countries.

To this end, the EU, in order to achieve full digitalisation of its economy by 2010, adopted the EU Digital Agenda (the Digital Agenda for Europe), which targets and tasks were set out up to 2020 [1]. The Digital Agenda for Europe represents one of the seven forward-looking initiatives of the Europe 2020 Strategy for growth and jobs aimed at better use of the Information and Communication Technologies (ICT). It shall align European policies in the ICT. The Digital Agenda aims at implementing the EU's Digital Single Market providing modern high-speed networks and compatible software, thus contributing to the sustainable economic and social growth [2].

Most of the EU countries consider it as a framework document and adopt relevant National Programs for the Development of Digital Society for 1 to 3 years setting short-term and long-term priority targets and indicators of meeting those targets. The following states have developed their plans for implementing broadband connection: Czech Republic (Digital Czech Republic); France (National Programme for Very High Speed Broadband); Slovak Republic (National Strategy for Broadband Access in the Slovak Republic). Certain countries (Sweden, Germany ${ }^{1}$, and Austria) have launched the adjustment of their national plan target indicators to the new target indicators of the EU broadband connection for 2025.

Within the framework of the EU Digital Agenda, the European Union adopted the Digital Single Market Strategy aimed at opening up the digital opportunities for people and businesses and strengthening the Europe's world-leading position in the digital economy [3]. The framework of this Program provided for the investments amounting to 300 bln Euro for 7 years.

In order to visualize its digital economy, the EU developed Digital Transformation Scoreboard measuring the EU and member states productivity over a wide range of areas, from communication and digital skills to business and public services digitalization. The Digital Transformation Scoreboard provides the data of Digital Economy and Society Index (DESI), as well as of the Europe's Digital Progress Report (EDPR).

Germany is a leader of EU transport digitalisation viewing the concept of Digital Transport as an Industry 4.0 component and focusing its effort on the four targets:

1. Transport infrastructure and logistics chains (warehouses, logistics hubs, railways etc.) digitalization:

a) establishment of the intellectual component for transport infrastructure (Logistik 4.0); this includes automating warehouse operations, automated workplace management in line with the Lean Manufacture principles.

b) logistics chains optimization by means of automated transport system which provides selfsustaining interaction of a warehouse with the order consolidation department. This goes beyond cost reduction only speeding up the delivery of goods to the final consumer.

2. Introducing industrial robotics as a key component for ensuring self-sustaining operation of the warehouse and logistics activities. Equipping the automated transport components with robot manipulators constitutes one of the objectives.

3. Management systems automation. Shifting towards brand new requirements to management systems is ongoing. Examples may include a variety of electronic assistants providing control over the decisions to be adopted. SAP company offers the software enabling the material flow planning and management systems interaction by means of wireless connection. Such technologies ensure best combination and stock of resources. Similar optimization applies to the process of vehicles accounting, mileage efficiency monitoring, and motor vehicles technical performance.

4. Automatic pilot systems (platooning) means simultaneous driverless movement of motor vehicles united into caravans (up to 10 motor vehicles) by means of wireless (WiFi) connection ${ }^{2}$.

\footnotetext{
${ }^{1}$ Germany has adopted already the second Program designed to cover the period of 2017 to 2022.

${ }^{2}$ Automatic pilot systems (platooning) means simultaneous driverless movement of motor vehicles united into caravans (up to 10 motor vehicles) by means of wireless (WiFi) connection.
} 
Poland established its Digitalisation Ministry (Ministerstwo Cyfryzacji), its activities to focus exclusively on the implementation of modern technologies with the view of facilitating the following: contacts with the Governments and civil servants, establishment and operation of business in Poland. In December 2014, under the framework of Europe 2020 strategy implementation, Poland adopted the Operational Programme Digital Poland for 2014 to 2020. The Program aims at enhancing digital funds for national development. Key priority targets for the digitalisation of economy as defined include as follows: general access to high-quality Internet, e-government and digital competences of the society [4].

In that regard, Point 8.5 of the Operational Programme Digital Poland for 2014 to 2020 emphasizes that the frameworks of this Program shall review the above targets only, whereas such issues as supporting the EU position of a world leader in the area of science, maintaining industrial leadership of the European businesses in the field of innovations and resolving issues in the areas that are the most important for the Europeans such as the climate change and demographic changes, sustainable transport and mobility or increasing the availability of renewable energy sources, will be subject to review within the framework of the Operational Programme Smart Growth.

The follow-up reviews key approaches towards defining the ITS. Due to the lack of a single worldwide approach towards defining the ITS components we have considered several definitions and classifications by recognized international and supra-national organizations.

Accordingly, the Research and Innovative Technology Administration (RITA) [5] classifies ITS into the following sub-categories: Intelligent Infrastructure and Intelligent Vehicles.

The Intelligent Infrastructure includes as follows:

- Arterial management (road traffic surveillance and control, traffic lane management, parking management, data transfer, compliance with road traffic rules).

- Highway traffic management (road traffic surveillance and management at entering the road, traffic lane management, emergency response, transport management, data transfer, compliance with road traffic rules).

- Accident prevention and road safety (informing of the road dimensions, pedestrian safety, alert system notifying of railway crossing; collisions; cyclists and animals).

- Traffic management subject to road weather conditions (control, monitoring and forecasting weather conditions, data transfer, advisory strategies, traffic management, management strategies, interpretation strategies).

- Operation and use of the roads (data collection and transfer, surveillance, operational space management).

- Carriage management (vehicle fleet management, data transfer, transport demand management, safety and security).

- Road events management (detection and control, mobilization and response, data transfer, obstacles removal and traffic resume).

- Emergency response management (first aid, emergency technical support and traffic resume).

- Electronic payments (fare, parking fee, multi-functional payment system, pricing system).

- Information for travellers (trip data, route data, tourism and events).

- Data management (backups).

- Commercial transport operation (administrating permits, ensuring safety, electronic screening, carriers and fleet management).

- Intermodal freight transportation (tracking of freights, security, freight terminal operation, carriage fee, freight motorways interconnection system, border crossing international processes).

Intelligent Vehicles include as follows:

- Collision avoidance system (obstacle detection, assisting in changing traffic lanes, traffic lane warnings; roll-over warning; warnings on drive-away; risk of collision; rear collision).

- Driver-assistance systems (navigation, dispatcher-to-driver connection, enhanced vision, objects detection, Adaptive Cruise Control, smart speed management, assistance in keeping traffic lane, roll-over prevention system, drowsy driver alert system, precision of coupling, mating/ unmating, on-board monitoring).

- Collision alert (automatic alert in the event of collision).

According to the classification proposed by the World Road Association (PIARC) [6], the ITS includes 32 user services, conventionally grouped into 8 categories:

1. road traffic management: supporting transport planning; road traffic management; emergency traffic management; transport requirements management; road traffic management policy; infrastructure technical operation management; 
2. information for travellers: pre-travel information; on-ride info for drivers; real-time traffic info for public transport; customized information; road guidance and navigation;

3. vehicle systems: enhanced identification; vehicle automated management; front collision avoidance; lateral collision avoidance; safety systems; accident avoidance systems;

4. commercial vehicles: preliminary custom operations for commercial transport; administrative processes for commercial transport; administrative roads safety inspections; commercial vehicles safety monitoring; commercial fleet management;

5. public transport: public transport management; on-request transport management; combined transport management;

6. emergency response management: hazard alarm and personal safety; emergency and rescue transport management; hazardous cargo; incident prevention;

7. electronic payments: electronic financial transactions;

8. safety: safety in general transport; safety for disabled persons; intelligent crossroads.

The key principles for putting the EU Intelligent Transport System in operation in the EU were established by the European Parliament and the Council of Europe on July 7, 2010 in their approved Directive 2010/40/EU [7]. The Directive defined the term 'Intelligent Transport Systems' as the program which applies information and communication technologies in the field of: 1) road transport, including infrastructure, vehicles and users; 2) traffic management and mobility management, as well as for interfaces with the other modes of transport. The Directive established compulsory conditions for the efficient EU-wide deployment of ITS.

EU sets out the following priority areas for the ITS development: 1) optimal use of road, traffic and travel data; 2) continuity of traffic and freight management, 3) ITS road safety and security applications, 4) linking the vehicle with the transport infrastructure.

Pursuant to the EasyWay European Global Program for 2007 to 2020 the following Projects were implemented: I EasyWay Projects (2007 to 2009) and II EasyWay Projects (2010 to 2012) as financed by the European Commission and constituting a part of this Program. EasyWay I and II are the Projects for deploying the Pan-European systems and services of ITS in the TEN-T road network and its interfaces with urban districts and other modes of transport. Both the EasyWay I and II were implemented by the national executive bodies governing the motor road issues in most of the EU member countries, as well as by public and private operators of roads and the associated partners closely cooperating with the other key stakeholders. As a key advantage, the EasyWay I and II have provided the unique European platform uniting the ministries, executive bodies governing the motor road issues and the road operators (both public and private) over all Europe facilitating closer ties between the key stakeholders enabling them to exchange know-how, advanced experiences included, and develop the Deployment Guiding Principles that ensure coherent deployment of the ITS while supporting the European transport policy. Pursuant to the EasyWay European Global Program [8] the ITS shall be classified as follows:

- Road services providing comprehensive real-time road information for the travellers so as to enable taking reasonable decisions prior to a trip, as well as information during the trip.

- Traffic management services providing the traveller with navigation data, detecting unusual and emergency circumstances relating to safe and efficient use of the road network.

- Freight and logistics technologies aimed at optimizing productivity and efficiency of the freight transport by way of ensuring safe and easy access to the intermodal terminals (ports, railways and motorways etc.).

In Ukraine, the Ordinance of the Cabinet of Ministers of Ukraine No. 67-p of January 17 approved the Conception for Developing Digital Economy and Society in Ukraine for 2018 to 2020 and adopted the Action Plan Implementing the Conception, which aimed, inter alia, at determining the indices, indicators and methods for assessing the digital development of Ukraine according to the international practices, and pursuant to this Plan the ministries and bodies concerned shall facilitate the digital development. In November 2017, the Ministry of Infrastructure of Ukraine established the Digitalization and Cyber Safety Industry Centre Daughter Company as a state enterprise [9]. The latter aims at implementing the cyber protection, digitalization and IT development programs, developing thereof, rapid response to the incidents related to the attempts of intervention into corporate, institutional and public IT systems operating in the transport industry. Moreover, the Ministry of Infrastructure of Ukraine established the Transport Digital Infrastructure Directorate supervising relevant issues [10]. So far, there is no official definition of the ITS at legislative level developed in Ukraine.

The review of the ITS definitions as adopted by both the international organizations and supranational establishments enables to deduce that the ITS development would be critical for providing the 
end-users with information from the systems controlling road situation in real-time mode and the opportunity for different operators at the national or cross-border level to ensure the compatibility and continuity of the services to be provided on the basis of unification of data as provided by the systems in use.

Therefore, the Intelligent Transport System as an integrated system corresponds to the following concept: transport infrastructure - vehicles - user. An innovative solution for transport issues would rather not deal with a transport management system to be developed focusing on the development of such transport systems which have their means of communication, control and management originally incorporated in the vehicles and relevant infrastructure facilities. To this end, the management opportunities (decision-making) based on the real-time data to be received in such systems are not restricted to the transport operators only being available to all the users of transport and management systems as a whole.

According to the ITS concept we have, by parity of reasoning, specified three functional blocks: I. Transport Infrastructure, II. Vehicles, III. User (Fig. 1). Each blocks, in it turn, splits into 5 systems of transport sector digital development indicators, as follows: I.1. E-Logistik, I.2. Smart roads, II.1. Vehicles management and monitoring, III.1. Safety management, III.2. Mobile apps. The systems of indicators as listed split into 18 functional subsystems representing both modern and envisaged transformation processes for digitalization in transport with the view of ensuring their success in the future. Each of the 18 subsystems has the relevant transport sector digital transformation indicators as set out that enable monitoring the transformation developments, holding assessments of digital transformations in progress that would constitute a basis for decision-making on ensuring the success for digital transformations in the transport industry.

According to the specific indicators of digital transformation development in transport sector, we have selected the possible indicators for assessing those transformations for transport sector (Table. 1-3). The system of indicators as established constitutes one of the ways for resolving challenges related to the development of statistical database for digital transformations in the transport industry facilitating the monitoring to be carried out for the transport industry transformation developments.

The follow-up briefly reviews the key indicators for each ITS block. Introduction of electronic logistics and smart roads development constitute the indicators of transport infrastructure intelligence.

FUNCTIONAL ARCHITECTURE OF DIGITAL TRANSFORMATIONS IN THE TRANSPORT SECTOR

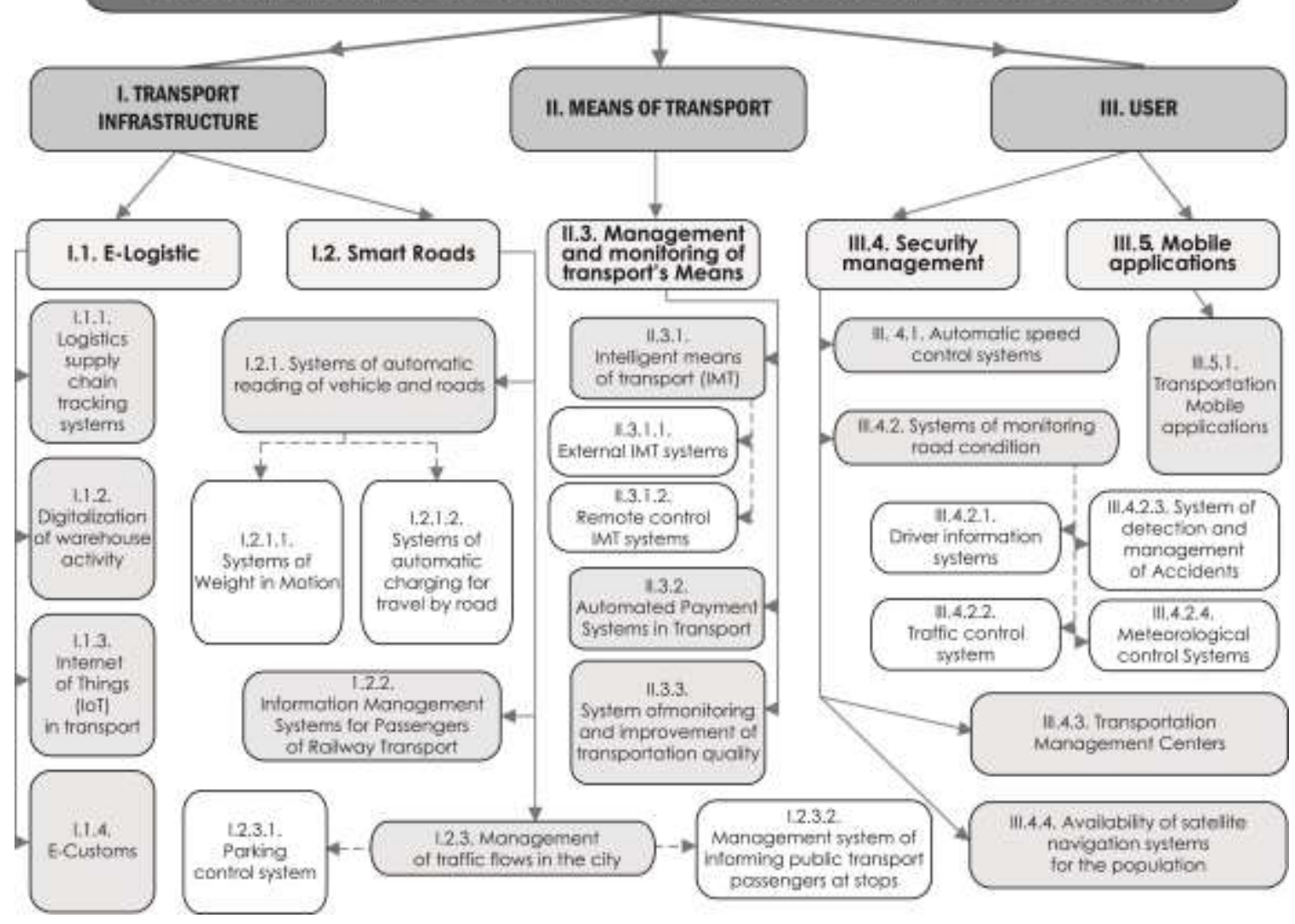

Fig. 1. Functional architecture of digital transformations in the transport sector 


\section{Transport Infrastructure (Table 1).}

$\boldsymbol{E}$-Logistics is the process governing anything related to on-line market. The key difference between logistics and electronic logistics lies in the fact that the classic logistics deal with planning, holding and controlling the supplies and stocks of commodities, services and relevant information, whereas the electronic logistics aims at applying Internet technologies for common logistics processes, that is, automation and digitalization of the logistics workflow. The processes inherent in electronic logistics include as follows: electronic payments; verifying product availability; arranging supplies; insurance; refilling stocks in logistics systems; contacting clients; arranging return of goods etc [11].

Smart Road means the one incorporating intellect and latest scientific achievements. It shall ensure safety, communication, and comfort. At the level of a regular user, the Smart Road shall help avoiding mistakes, adopting optimal route decisions and enjoying the use. At the macro-level, the Smart Road network shall ensure even flow of traffic, road users observing the applicable rules, big data and analytics collection, timely re-distribution of flows, weighing during the ride etc [12].

Table 1. Digital Transformation Indices for Transport Sector for the ITS Development Indicating Systems: Transport Infrastructure

\begin{tabular}{l} 
I.1 E-Logistik \\
\hline I.1.1. System tracing logistics chain of supplies: \\
- number of crowd-sourcing platforms, units \\
- number of freight trucks returning from their rides with empty loads, units \\
- RFID-markings on the container, units \\
- number of the logistics companies controlling the actual route of mobile objects with satellite \\
navigation systems or cellular communication systems, units \\
- proportion of logistics companies controlling the actual route of mobile objects with satellite \\
navigation systems or cellular communication systems, in the total number of logistics companies, \% \\
- number of electronic seals used by Ukrainian logistics companies, units. \\
- average number of electronic seals used as expressed per a logistics company, units. \\
\hline Digitalization in operation of warehouse activities \\
- number of warehouses equipped with robot manipulators, units. \\
- number of logistics hubs, units. \\
- area of logistics hubs, thousand m ${ }^{2}$ \\
- number of logistics enterprises equipped with automated transport systems (logistics enterprises \\
using ITS), units. \\
\hline Internet of Things (IoT) technology in transport: \\
- number of mobile operators providing IoT service. \\
- country area covered by IoT, \%. \\
- number of devices using IoT, units \\
- number of port infrastructure facilities connected to the IoT, units \\
- number of smart sensors known as the digital dolphins, installed in sea ports, units. \\
\hline Electronic custom house: \\
- number of custom clearance declarations filed electronically, units \\
- proportion of custom clearance declarations filed electronically, \%. \\
\hline
\end{tabular}


Continuation of table 1

Systems managing notifications for railway transport passengers:

- number of railway stations furnished with electronic boards providing on-line information to their passengers, units

- proportion of railway stations furnished with electronic boards providing on-line information to their passengers, in the total number of railways stations, $\%$

- number of platforms furnished with electronic platform displays providing on-line information to their passengers, units

- proportion of platforms furnished with electronic boards providing on-line information to their passengers, in the total number of platforms, $\%$

- number of infomats, units.

\section{Urban transport flows management:}

1. Parking management systems:

- number of parking sites furnished with the system providing information to a mobile app that accounts parking slots available, units

- number of mobile apps displaying slots available at the parking lot, units.

\section{Systems managing notifications for public transport passengers at stops:}

- number of public transport stops furnished with passenger notification systems, broken down by modes of transport (bus, tram, trolleybus, heavy rail), units

- proportion of public transport stops furnished with passenger notification systems, in their total number, $\%$.

"Source: as drafted by the contributors.

\section{Vehicles (Table 2)}

Intelligence for vehicles provides for their management and monitoring to be carried out by means of digitalized technological innovations with the view of enhancing safety, maintaining quality, ensuring on-line control over traffic schedule of all the vehicles, fleet operation efficiency, boosting the productivity of workers operating the carriages, comfort level etc. This is a prospective and efficient solution in the transport industry meeting the needs of both passenger and freight carriage.

Table 2. Digital Transformation Indices for Transport Sector for the ITS Development Indicating Systems: Vehicles

\begin{tabular}{|l|}
\hline \multicolumn{1}{|c|}{ Vehicles management and monitoring } \\
\hline Intelligent Vehicles include as follows: \\
\hline 1. Intelligent Vehicle external systems: \\
- number of vehicles equipped with smart vehicle external systems, units. \\
\hline 2. Vehicle remote control systems: \\
- number of pilot-free motor vehicles, units \\
- number of pilot-free smart trains, units \\
- number of pilot-free airborne cargo-delivery vehicles, units. \\
\hline Automated fare collection: \\
- number of tickets sold, broken down by mode of transport, units \\
- number of all-transport tickets sold, units \\
- number of turnstiles in heavy rail transport, units \\
- number of heavy rail transport turnstiles equipped with all-transport ticket system, units \\
- number of validators in public transport, units, \\
including \\
- stationary units \\
- portable units \\
- proportion of public transport vehicles equipped with validators, in their total number, \% \\
- number of points for public transport electronic ticket recharge, units \\
- number of cities that have all-transport ticket system for public transport introduced, units.
\end{tabular}


Continuation of table 2

Monitoring system for boosting transport carriage quality:

- number of freight vehicles equipped with GPS sensors, units

- RFID labels at rail-road cars, units

- rolling stock units equipped with trackers, units.

- number of locomotives equipped with on-board smart suites (SSN), units

- proportion of locomotives equipped with on-board smart suites, in the total number of locomotives, (SSP), \%

- number of vehicles equipped with fuel flow meters, units

- number of GPS-equipped buses operating international passenger carriages, units

- number of WiFi-equipped buses operating international passenger carriages, units

- number of public transport vehicles equipped with WiFi system, units

- number of public transport stops with WiFi system available, units

- number of public transport vehicles equipped with GPS, units

- number of taxi service vehicles operating on electronic platform and linking partner drivers with the

clients using a mobile app, units

- number of river ports furnished with ITS, units.

- number of marine crafts equipped with satellite navigation systems, units

- proportion of marine crafts equipped with satellite navigation systems, in their total number, $\%$.

"Source: as drafted by the contributors.

\section{User (Table 3)}

Safety management system is a set of systems operating to maintain safety over the entire way and capable, in automated mode, of recording and disclosing without human intervention such dangerous non-compliances as: 1) speed limit violation; driving past prohibiting traffic light; 2) crossing stop-line past prohibiting traffic light; 3) vehicle crossing boundary marking; 4) driving in the oncoming traffic lane; 5) turning from ineligible lane; 6) stopping at ineligible site; 7) driving at public transport lane; 8) non-compliance with the requirements provided for by road signs or markings of road traffic lanes; 9) Railroad crossing rules violation etc [13].

The key trends in worldwide development of urban transport apps (other than the applications designed for car navigation) assisting their users so that they could get oriented in the city transport infrastructure, include as follows: increased popularity of applications for cyclists; using 3D maps featuring in-depth details; demand for multifunctional transport apps (bundling several public transport modes in one app/searching and paying for parking etc.); the option of fare payment and transport card recharging immediately with the mobile app.

Table 3. Digital Transformation Indices for Transport Sector for the ITS Development Indicating Systems: User

\begin{tabular}{|l|}
\hline \multicolumn{1}{|c|}{ Safety management } \\
- number of remote meters of travelling speed (radars), units \\
- road network length as covered by automatic speed control system, $\mathrm{km}$ \\
- proportion of road network length as covered by automatic speed control system, in the roads total \\
length, \%. \\
\hline Road conditions monitoring systems \\
\hline 1. Driver notification system: \\
- number of electronic road information displays, units \\
- length of the road network that provides information on road traffic and rides, km \\
- proportion of the road network that provides information on road traffic and rides, in the total length \\
of the roads, \%. \\
\hline 2. Traffic control system \\
- number of road sensors, units \\
- number of photo and video recording cameras, units \\
- number of crossroads controlled by automatic signals, units \\
- proportion of crossroads controlled by automatic signals, \% \\
- number of automatic traffic lights, units.
\end{tabular}


Continuation of table 3

\begin{tabular}{l} 
3. Systems for detecting and managing road traffic accidents (RTA): \\
- number of non-compliances with road traffic rules as registered by the RTA detection and \\
management systems, units \\
- proportion of such non-compliances in the total number of the accidents, \% \\
- number of RTA as recorded by the RTA detection and management systems, units \\
- road network length covered by the RTA detection and management systems, units \\
- proportion of road network length covered by the RTA detection and management systems, in the \\
total road length, \%. \\
\hline 4. Meteorological monitoring systems: \\
- number of automatic road weather stations, units \\
\hline Transport management circumstantial centres: \\
- number of transport management circumstantial centres, units \\
\hline Availability of satellite navigation systems for the public: \\
- number of satellite navigation system maps, units. \\
\hline \multicolumn{1}{c|}{ Mobile apps } \\
Transport mobile apps: \\
- number of businesses developing and distributing software for the Intelligent Stops and for the \\
- number of transport mobile apps as available to the Ukrainian users, broken down by their types: \\
- overland public transport, units \\
- heavy rail transport, units \\
- taxi, units \\
- personal transportation, units.
\end{tabular}

"Source: as drafted by the contributors.

Conclusions. The ITS development is of strategic nature as this determines competitiveness for each country in general at the world market. Besides, as long as transport sector is critical for implementing most of the services related to trading, production, construction, the ITS may offer their solutions for a range of transport tasks which are capable of improving the intelligent use of the existing capacity and infrastructure, reduce losses of energy and resources through more efficient use of the transport system as a whole. Last but not least, the efficiency delivered by the ITS relates, as a rule, to the productivity of macroeconomic systems and, therefore, provides for the growing multiplier effect.

The review of EU Digital Agenda and other high level documents demonstrates that most of the EU countries consider it as a framework document and adopt their relevant National Programs for the Development of Digital Society for 1 to 3 years setting short-term and long-term priority targets and indicators of meeting those targets.

The review of Intelligent Transport System definitions and classifications as adopted by both the international organizations and the supranational establishments enables to deduce that the Intelligent Transport System as an integrated system corresponds to the following concept: transport infrastructure vehicles - user, and the ITS digital infrastructure development would be critical for providing the end-users with information from the systems controlling road situation in real-time mode and the opportunity for different operators at the national or cross-border level to ensure the compatibility and continuity of the services to be provided on the basis of unification of data as provided by the systems in use.

According to the ITS concept we have, by parity of reasoning, specified three functional blocks: I. Transport Infrastructure, II. Vehicles, III. User, each, in their turn, spiting into 5 systems of transport sector digital development indicators as follows: I.1. E-Logistik, I.2. Smart roads, II.1. Vehicles management and monitoring, III.1. Safety management, III.2. Mobile apps. The systems of indicators as listed split into 18 functional subsystems representing both modern and envisaged transformation processes for digitalization in transport with the view of ensuring their success in the future. Each of the 18 subsystems has the relevant transport sector digital transformation indicators as proposed that enable monitoring the transformation developments, holding assessments of digital transformations in progress that would constitute a basis for decision-making on ensuring the success for digital transformations in the transport industry.

The proposed system of indicators, based on the transport digital transformation systems as specified, is ongoing and could be updated with other indices as the transport sector digital transformations 
are unfolding. Considering the modern trends in the world as regards the growing infiltration of the digital technologies into all the spheres of human activities, the system in question goes beyond its use for monitoring of the above processes only being readily available for the management activity routines.

\section{REFERENCES}

1. The official site of European Commission "Digital agenda for Europe/Luxembourg: Publications Office of the European Union" (2014). URL: https://eige.europa.eu/resources/digital_agenda_en.pdf

2. The official site of Austrian Research Promotion Agency FFG "Digital Austria". URL: https://www.digital.austria.gv.at/digital-agenda-for-europa

3. The official site of European Commission "Digital Single Market". Germany has adopted already the second Program designed to cover the period of 2017 to 2022. URL: https://ec.europa.eu/digital-single-market/en

4. The official site of Managing Authority of the Digital Poland Program. Department of Digital Development at the Ministry of Investment and Development "Digital Poland for 2014-2020-Polska Cyfrowa". URL: https://www.polskacyfrowa.gov.pl/media/10410/POPC_eng_1632015.pdf

5. The official site of US Department of Transportation. RITA (Research and Innovative Technology Administration). URL: https://www.transportation.gov/

6. Rudzins'ka, O.V., Bezzub, Yu.V. and Shumlyakivs'kyj, V.P. (2016), "Processes of development of motor transport technologies in intelligent transport systems", Visnyk ZhSTU. - № 2(77), pp. 230-237. (in Ukrainian).

7. The official site of European Union Law "Directive 2010/40/EU of the Europian Parliament and of the Council of 7 July 2010 on the framework for the deployment of Intelligent Transport Systems in the field of road transport and for interfaces with other modes of transport". URL: http://eurlex.europa.eu/LexUriServ/LexUriServ.do?uri=OJ:L:2010:207:0001:0013:EN:PDF>.

8. The official site of European ITS Platform "The EasyWay Programme (2007-2020)" and its Projects. URL: https://www.its-platform.eu/highlights/easyway-programme-2007-2020-and-its-projects

9. Ministry of Infrastructure of Ukraine (2018), The Order of the Ministry of Infrastructure of Ukraine "On some issues of the state enterprise "Sector Center of Digitalization and Cybersecurity activity"', URL: https://mtu.gov.ua/documents/983.html. (in Ukrainian).

10. Ministry of Infrastructure of Ukraine (2018), Directorate of Digital Transport Infrastructure. URL: https://mtu.gov.ua/content/direktorat-derzhavnoi-politiki-u-sferi-cifrovoi-infrastrukturi-na-transporti-taposlug-poshtovogo-zvyazku.html. (in Ukrainian).

11. Fedyaj, N.O. (2018), "Calculation of digital transformations in logistics", Statystychne ta ekspertnoanalitychne zabezpechennia upravlinnia stalym rozvytkom ekonomiky $i$ social'noi sfery. Suchasni kompiuterni texnologii analizu danykx ta statystyky: zbirnyk materialiv [Statistical and expert-analytical support for the management of sustainable development of the economy and social sphere. Modern Computer Technologies for Data Analysis and Statistics: A Compilation of Materials], IV Mizhnarodna naukovo-praktychna konferencia [IV International Scientific and Practical Conference], Chernihiv National Technological University, Ukraine, pp. 97- 100. (in Ukrainian).

12. Chmyrova, L.Yu. (2018), "Indicators of digital transport transformation", Statystychne ta ekspertnoanalitychne zabezpechennia upravlinnia stalym rozvytkom ekonomiky $i$ social'noi sfery. Suchasni kompiuterni texnologii analizu danykx ta statystyky: zbirnyk materialiv [Statistical and expert-analytical support for the management of sustainable development of the economy and social sphere. Modern Computer Technologies for Data Analysis and Statistics: A Compilation of Materials], IV Mizhnarodna naukovo-praktychna konferencia [IV International Scientific and Practical Conference], Chernihiv National Technological University, Ukraine, pp. 90-94. (in Ukrainian).

13. Stasyuk, O.M. (2018), "Indicators of digital transformation of road monitoring systems", Statystychne ta ekspertno-analitychne zabezpechennia upravlinnia stalym rozvytkom ekonomiky i social'noi sfery. Suchasni kompiuterni texnologii analizu danykx ta statystyky: zbirnyk materialiv [Statistical and expert-analytical support for the management of sustainable development of the economy and social sphere. Modern Computer Technologies for Data Analysis and Statistics: A Compilation of Materials], IV Mizhnarodna naukovo-praktychna konferencia [IV International Scientific and Practical Conference], Chernihiv National Technological University, Ukraine, pp. 84-87. (in Ukrainian). 